\title{
Breeding waders and their conservation on the wetlands of Tiree and Coll, Inner Hebrides
}

\author{
K.B. SHEPHERD and DAVID STROUD
}

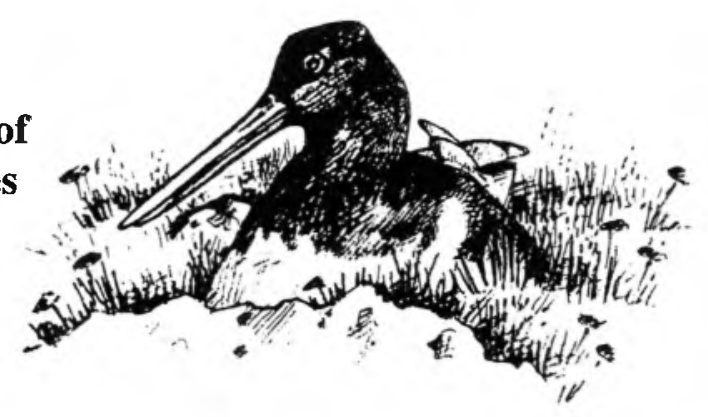

Breeding wader populations on a range of machair and other wetland biotopes on the Hebridean islands of Tiree and Coll were surveyed in 1987 and 1988. Six species breed, five of them (Lapwing, Redshank, Oystercatcher, Ringed Plover, Dunlin and Snipe) in nationally important numbers. Habitat selection was investigated on nine sample survey sites, and extrapolated results indicate that a total of 6020 pairs of waders bred on Tiree, and 1330 on Coll. Several wetland and machair habitats held large numbers of breeding birds. Of particular importance were small areas of marsh and fen, wet machair, Phragmites beds, coarse wet pasture and old decaying runways set in areas of dry machair. The extent of European machair has been surveyed for breeding waders in the last five years. Tiree and Coll, together with the southern isles of the Outer Hebrides, hold internationally important populations, and are important in maintaining the range of several species within the British Isles (as required by international legislation). Agricultural operations, specifically drainage and intensification of grassland management, could be damaging to currently prime wader habitats. As well as protection of key areas, long-term conservation of these populations would be achieved by support for traditional forms of crofting which, over past centuries, has created the agricultural landscape on these islands.

Machair is the Gaelic name for coastal grasslands which develop under an extremely limited range of conditions in Europe. They occur where offshore, calcareous shell-sand is washed and blown onshore to form low coastal landforms, and are frequently associated with traditional systems of low-intensity agriculture and crofting tenure (Caird 1979). Their topography results in extensive winter flooding, some areas remaining wet throughout the year thus providing a range of breeding and feeding opportunities for wildfowl and waders.

In Europe, machair grasslands occur in the Atiantic seaboard of the British Isles, from isolated areas in Shetland and Orkney in the north, to the extreme west of Ireland; however, they attain their greatest development in the southern islands of the Outer Hebrides (Ritchie 1976). Small areas occur also in some Inner Hebridean islands such as Colonsay, Islay and Iona although the greatest extent in this island group occurs on the islands of Tiree and, to a iesser extent, Coll.

Between 1983-87, the Wader Study Group and the Nature Conservancy Council (NCC) undertook breeding wader surveys on the machair of the southermmost Outer Hebrides
(Fuller et al. 1986, Fuller \& Percival 1988, Jackson 1988). The surveys found internationally important wader populations and demonstrated that their conservation should be of major significance in future land-use considerations. Information from Tiree and Coll (C.J. Cadbury unpubl., Fuller 1982, Reed et al. 1983) suggested that machair on these islands was characterised by a breeding wader community similar to the Outer Hebrides, although the machair is not agriculturally managed in the same fashion (Vose et al. 1959, Harrison 1989). A range of other wetland habitats occur on the islands (Wormell 1989), of which damp acid grassiands and heath-dominated vegetation are the most abundant. Centuries of human use has stripped away most peat on Tíree for use as domestic fuel and the resulting vegetation communities are much modified compared with those of moorlands and blanket bogs elsewhere (e.g. Stroud et al. 1987).

In 1986, the EEC proposed an Agricultural Development Programme (ADP) for the Inner Hebrides, running for five years from April 1988. The ADP acknowledges conservation principles (SDD 1988) but nevertheless has scope to cause local damage to features of 


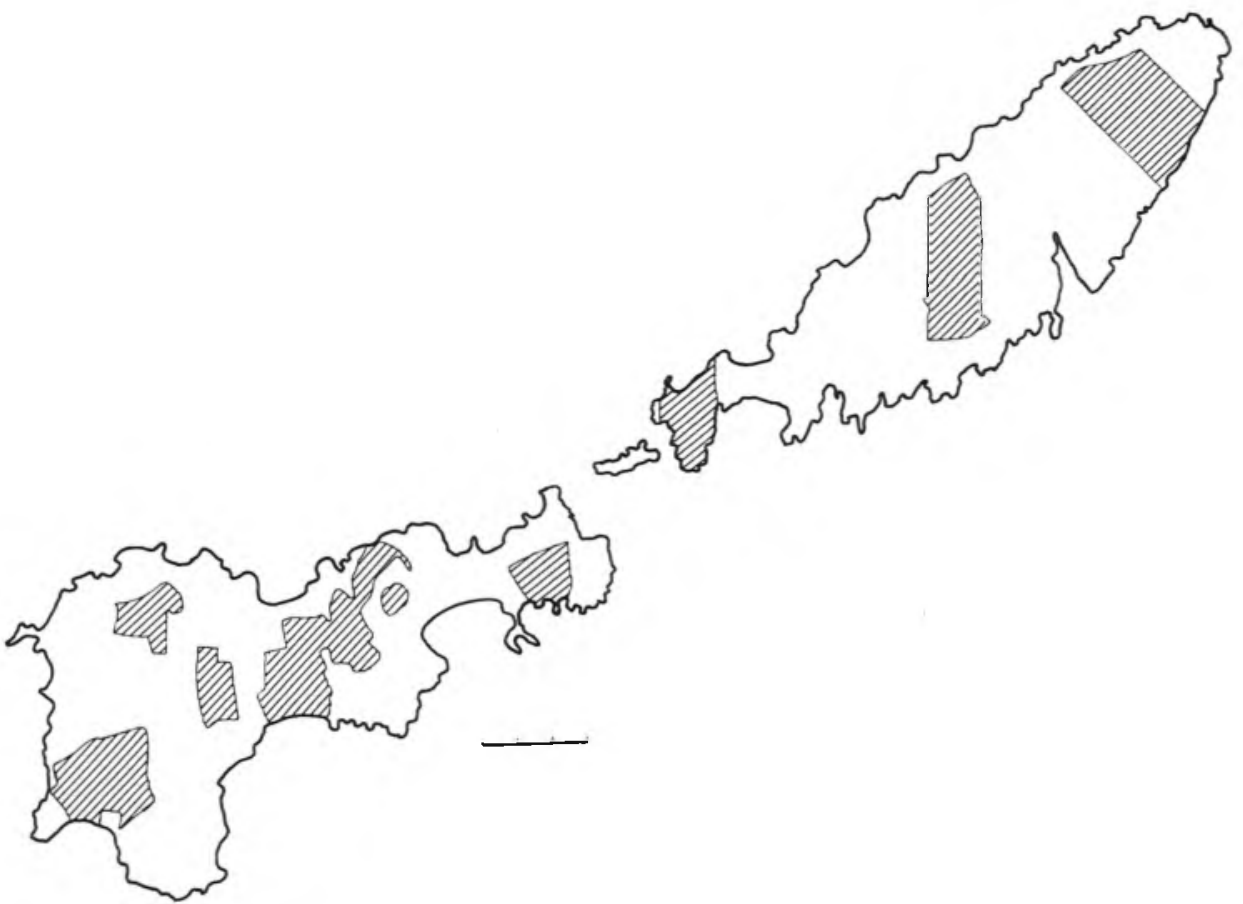

Figure 1. The islands of Coll and Tiree, Scotland showing location and extent of survey sites. Scale is $3 \mathrm{~km}$.

conservation importance. This is especially so where drainage of wetlands will adversely affect conditions attractive to large numbers of breeding waders and other waterfowl. For this reason, identification of features of conservation interest is essential so that advice can be given to assist the fulfilling of the conservation principles.

A comprehensive survey of breeding wader populations of Tiree and Coll was therefore undertaken a) to quantify numbers and distribution; b) to identify important wader habitats and record variation in breeding density within and between these; and c) to provide advice on the conservation implications of any proposed land-use changes. Surveys were carried out by the Moorland Bird Study of NCC's Chief Scientist Directorate in 1987 and 1988 and fully reported by Shepherd et al. 1988, Shepherd 1988 and Stroud 1989. This paper summarises the main findings.

\section{Methods}

Based on available information on habitat distribution (P. Wormell pers. comm.), sample sites were chosen which covered the full range of habitats across both isles (Fig. 1). Each was surveyed for breeding waders using methods similar to those of the JNCC/BTO Common Birds Census, plotting onto 1:10,000 scale maps the locations and activities (cf. Reed \& Fuller 1983) of all birds seen on each of four visits. In 1987, surveys were undertaken between 20 April-28 June, whilst in 1988 site visits were made between 9-23 April. During each visit, all parts of the sites were systematically searched, in agricultural areas on a field-by-field basis, whilst other areas were surveyed by using transects $150 \mathrm{~m}$ apart (but deviating to cover areas hidden from sight or areas of habitat potentially concealing birds). Emphasis was placed on scanning areas before approaching and allowing disturbed birds to settle so locations could be precisely mapped on the detailed maps. This was particularly important in very high density areas. Care was taken not to double-record individual birds as indicated by Shepherd et al. 1988.

Breeding birds were identified in the field by observation of at least one of the following: song/display; bird carrying nest-material; location of nest or young; repetitive alarm-calling or distraction display indicating nearby presence of nest or young; or birds carrying food.

At the end of the season, all visit maps for each site were examined in combination in 
Table 1. Characteristics of blotopes mapped on Tiree and Coll as potential wader breeding habitats

\begin{tabular}{|c|c|c|c|c|c|}
\hline \multirow{2}{*}{ Habitat } & \multirow{2}{*}{$\begin{array}{l}\text { Vegetation } \\
\text { Pioneering Ammophila on yellow dunes - } \\
\text { grey dunes with calcareous grassland } \\
\text { species }\end{array}$} & \multirow{2}{*}{$\begin{array}{l}\text { Micro-topography } \\
\text { Sandy hills and hillocks } \\
\text { with blow-outs }\end{array}$} & \multirow{2}{*}{$\begin{array}{l}\text { Management } \\
\begin{array}{l}\text { Mainly winter stock } \\
\text { grazing }\end{array}\end{array}$} & \multicolumn{2}{|c|}{$\begin{array}{l}\text { AREA (ha) ON } \\
\text { TIREE COLL }\end{array}$} \\
\hline & & & & 205 & 710 \\
\hline Machair & $\begin{array}{l}\text { Botanical composition resembles grey } \\
\text { dune pastures }\end{array}$ & & & & \\
\hline Dry machair & Dry substrate in summer & $\begin{array}{l}\text { Variable and created by } \\
\text { drainage and grazing }\end{array}$ & $\begin{array}{l}\text { Mainly winter stock } \\
\text { grazing }\end{array}$ & 1685 & 230 \\
\hline Wet machair & $\begin{array}{l}\text { Increased frequency of Ranunculaceae } \\
\text { and decreace in Festuca rubra cf. dry } \\
\text { machair ares }\end{array}$ & $\begin{array}{l}\text { Variable, more uneven as } \\
\text { wetness increases. High } \\
\text { incidence of tussock } \\
\text { forming species }\end{array}$ & $\begin{array}{l}\text { Mainly winter stock } \\
\text { grazing: many ditches } \\
\text { may occur }\end{array}$ & 145 & 30 \\
\hline Agrkultural land & $\begin{array}{l}\text { Enclosed agricultural land, probably } \\
\text { all originally derived from machair } \\
\text { habitats, and all bese-rich }\end{array}$ & & & & \\
\hline Plough & Bare soil & $\begin{array}{l}\text { Sandy or stoney depending } \\
\text { on substrate }\end{array}$ & $\begin{array}{l}\text { Future cereals or root } \\
\text { crops }\end{array}$ & 150 & 15 \\
\hline Uniform dry pasture & Botanically herb-rich on dry substrates & Uniform short sward & Grazing & 1270 & 160 \\
\hline Coarse dry pasture & $\begin{array}{l}\text { Shallow soils in rocky areas: dry sub- } \\
\text { strates dominated by tussocky grasses }\end{array}$ & $\begin{array}{l}\text { Uneven and often poached } \\
\text { by animals }\end{array}$ & Poor grazing areas & 440 & 180 \\
\hline Uniform wet pasture & $\begin{array}{l}\text { As above but with more wetland species. } \\
\text { Often occurs as late successional stage } \\
\text { of drainage of wetter biotopes }\end{array}$ & $\begin{array}{l}\text { Often pouched but } \\
\text { generally uniform } \\
\text { conditions }\end{array}$ & Grazing & 200 & 250 \\
\hline Coarse wet pasture & $\begin{array}{l}\text { High incidence of Juncus and Cirsium } \\
\text { spp. Coltha polustris dominant with } \\
\text { tussocky grasses and sedges }\end{array}$ & $\begin{array}{l}\text { Wet substrates and uneven } \\
\text { swards }\end{array}$ & Poor grazing areas & 650 & 185 \\
\hline $\begin{array}{l}\text { Agriculturally } \\
\text { intensified pasture }\end{array}$ & Dominated by Lolium perenne & Generally uniform & $\begin{array}{l}\text { Hay and silage } \\
\text { production in summer }\end{array}$ & 215 & 5 \\
\hline Acid beath biotopes & $\begin{array}{l}\text { Generally overlying rocky areas and } \\
\text { mimic montane dwar-shrub biokopes }\end{array}$ & & & & \\
\hline Short wet heath & Wet dwarf shrub heath & Vegetation $<20 \mathrm{~cm}$ & $\begin{array}{l}\text { Common grazings- } \\
\text { Usually over-grazed or } \\
\text { over-burnt }\end{array}$ & 410 & 15 \\
\hline Short dry heath & Dry dwarf shrub hestb & Vegetation $<20 \mathrm{~cm}$ & $\begin{array}{l}\text { Common grazings. } \\
\text { usually over-grazed or } \\
\text { over-bumt }\end{array}$ & 610 & 225 \\
\hline Deep heath & $\begin{array}{l}\text { Dominated by Colluna, Erica tetralix, } \\
\text { E cinerea, Vaccinium, Empetrum and } \\
\text { Eriophorum spp. }\end{array}$ & $\begin{array}{l}\text { Vegetation height } 20 \mathrm{~cm}^{-} \\
1 \mathrm{~m} \text {, sometimes deeper }\end{array}$ & Low intensity grazing & 255 & 2030 \\
\hline $\begin{array}{l}\text { Wet acidic } \\
\text { grassland }\end{array}$ & $\begin{array}{l}\text { Dominated by Molinia caerulea, Nardus } \\
\text { stricta, Juncus squarrasus, Tricophorum } \\
\text { and archid spp. }\end{array}$ & Badly drained acid soils & $\begin{array}{l}\text { Grazing intensity } \\
\text { modifies floristics }\end{array}$ & 120 & 1020 \\
\hline $\begin{array}{l}\text { Dry scidic } \\
\text { grassland }\end{array}$ & $\begin{array}{l}\text { Dominated by Nardus, Molinia, } \\
\text { Deschampsia, Callura absent or } \\
\text { sub-dominant }\end{array}$ & $\begin{array}{l}\text { Well drained dry acid } \\
\text { soils }\end{array}$ & $\begin{array}{l}\text { Grazing, intensity } \\
\text { modifies floristics }\end{array}$ & 490 & 670 \\
\hline $\begin{array}{l}\text { Modified blanket } \\
\text { bog }\end{array}$ & $\begin{array}{l}\text { Blanket bog with variable depth of } \\
\text { peat substrate. Variabie proportions } \\
\text { dwarf shrubs, Eriophorum, Molinia and } \\
\text { bog pools }\end{array}$ & Uneven & $\begin{array}{l}\text { Past peat-cutting or } \\
\text { other human impact has } \\
\text { modified }\end{array}$ & 15 & 950 \\
\hline \multicolumn{6}{|l|}{ Otber blotopes } \\
\hline Reed beds & Dominated by Phragmites australis & $\begin{array}{l}\text { Ditches and more } \\
\text { extensive waterlogged } \\
\text { soils }\end{array}$ & None & 25 & 25 \\
\hline Iris beds & Dominates by lris pseudocurus & $\begin{array}{l}\text { Often in wet field } \\
\text { comers }\end{array}$ & None & 200 & 220 \\
\hline Marsh and fen & $\begin{array}{l}\text { Very wet with standing water, dominated } \\
\text { by floating/emergent vegetation e.g. } \\
\text { Menyanthes trifoliota, Caliho palustris, } \\
\text { and Juncus spp. }\end{array}$ & $\begin{array}{l}\text { Variable, includes } \\
\text { overgrown ditches }\end{array}$ & Some limited grazing & 105 & 0 \\
\hline Juncus beds & $\begin{array}{l}\text { Continuous areas of Juncus spp. in } \\
\text { wet areas. Usually } J \text {. effusus, or } \\
J \text {. inflexus with } J \text {. conglomeralus } \\
\text { occasional }\end{array}$ & Uneven & $\begin{array}{l}\text { Often results from } \\
\text { grazing of other } \\
\text { biotopes }\end{array}$ & 195 & 35 \\
\hline Old runways & War-time runways st in dry machair & $\begin{array}{l}\text { Break-up and decay have } \\
\text { created shingle-like areas }\end{array}$ & None & 2 & 0 \\
\hline TOTAL AREAS & & & & 7487 & 7030 \\
\hline
\end{tabular}




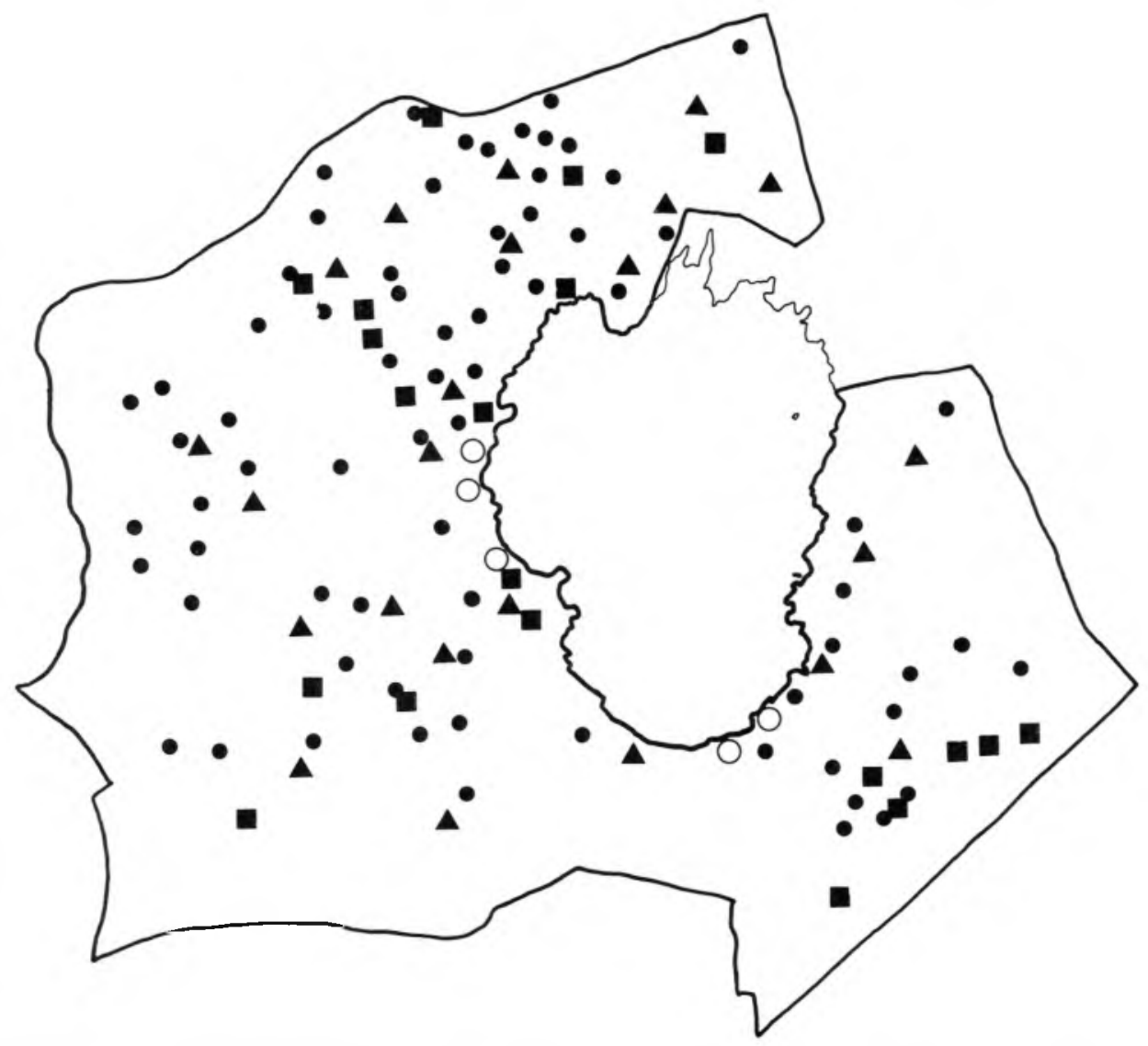

Figure 2. Loch a'Phuill survey site on Tiree showing locations of breeding wader territories (closed circle = Lapwing (72), square $=$ Redshank (20), triangle $=$ Oystercatcher (23) and open circle $=$ Dunlin (5)).

order to determine the number and locations, of pairs of breeding waders. This was taken as the largest number recorded on any single visit. However, during the visit when peak numbers were found there were occasional pairs that, although detected on other visits, were not seen. Thus, any pairs tha: were clearly additional to ones recorded on that visit were added to the maximum count on the basis of evidence from other visits to give an aggregate total.

Sites were specifically surveyed for Snipe between 24 May-9 June 1988, when they were visited twice soon after dawn and twice in the evening (when greatest drumming activity occurs: Green 1985, Reed 1986). All sites were visited by two observers who walked $100 \mathrm{~m}$ apart and recorded detailed locations of drumming birds, nests, and flushed and calling birds. Habitat use was determined by observations of drumming Snipe landing, observations of flushed and calling birds, and locations of nests. Care was taken not to double-record in areas of high density. Further details of bird survey methods are given by Shepherd et al. 1988.

A total of 1450 ha was surveyed on Tiree and 1420 ha on Coll representing c. $20 \%$ of each island. Not all was machair, and on Coll especially, a large extent of heath and moorland was surveyed. Vegetation maps were compiled for the whole of both isles. Twenty categories were used in the analysis: dunes, dry machair, wet machair, Phragmites beds, iris beds, marsh/fen, Juncus beds, plough, uniform dry pasture, coarse dry pasture, uniform wet pasture, coarse wet pasture, agriculturally intensified pasture, short wet heath, short dry heath, deep heath, wet acid grassland, dry acid grassland, modified blanket bog and old runways. These are briefly described in Table 1 and further details are given by Shepherd et al. 1988. It is important to note that the biotope classification was devised specifically to investigate selection by breeding waders. Thus biotopes such as coastal cliffs, 


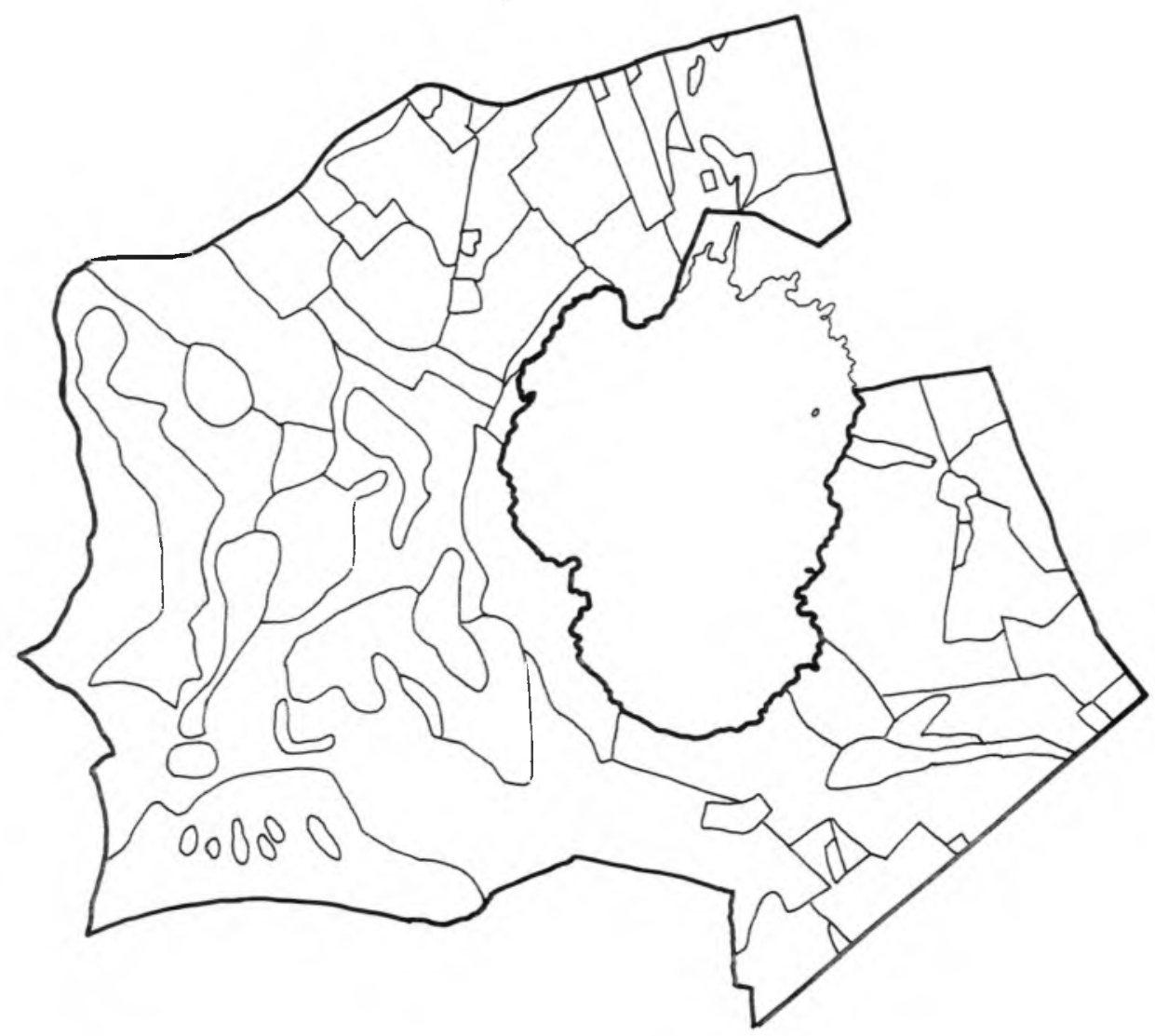

Figure 3. Loch a'Phuill survey site on Tiree showing boundaries of mapped wader habitat types (full details of habitats given by Shepherd et al. 1989). Note the intimate habitat mosaic in the north and east of the site associated with areas of crofts, whilst the south and east of the site has more uniform dune and dry machair habitat. These relate to areas of higher and lower wader densities respectively (Fig. 2).

open water etc., important for other groups of birds, were not included as they did not contain breeding waders. Beaches were not surveyed, although these habitats were of importance for breeding Ringed Plovers and Oystercatchers.

Combination of wader distribution maps (Fig. 2) and habitat maps (Fig. 3) for each of the sample sites, allowed comparison of breeding densities for each species between all habitats. Total wader populations were estimated for each isle by calculating the total area of each biotope and extrapolating using the densities of waders found in the sample survey sites.

\section{Results}

Wader breeding densities within habitats

Table 2 gives breeding densities for each wader species in each wader habitat as well as overall breeding densities for all species combined. Habitats are listed in decreasing order of overall breeding densities.

Lapwings Vanellus vanellus were more ubiquitous than other waders (Table 2). Particularly high densities ( $>29$ pairs $/ \mathrm{km}^{2}$ ) were found on dry machair, wet machair, coarse wet pasture, plough and short wet heath, with moderate densities (16-28 pairs $/ \mathrm{km}^{2}$ ) on marsh/fen, coarse dry pasture and uniform dry pasture and lower densities ( $<16$ pairs $/ \mathrm{km}^{2}$ ) on most other habitats. No Lapwings bred in reed-beds or on the old runways at Tiree Airport.

The highest breeding densities ( $>10$ pairs) $\mathrm{km}^{2}$ ) of Redshanks Tringa totanus were found in wetter habitats, particularly marsh/fen, wet machair, reedbeds (actually breeding in the sparse, short Phragmites, not the denser beds), coarse wet pasture and iris beds. A few pairs 
Table 2. Breeding densities (pairs $/ \mathrm{km}^{2}$ ) of waders found within habitats surveyed on Tiree and Coll. Habitats are listed in order of decteasing overall wader densities, and those containing above average densities for individual species are indicated by an asterisk.

\begin{tabular}{|c|c|c|c|c|c|c|c|}
\hline Wader habitat & $\begin{array}{l}\text { Overall wader } \\
\text { density }\end{array}$ & Lapwing & Redshank & Oystercatcher & Ringed Plover & Dunlin & Snipe \\
\hline Old runways' & 2500.0 & & & $100.0^{\star}$ & $2400.0^{*}$ & & \\
\hline Marshes and fens & 750.9 & $22.9 *$ & $128.4^{\star}$ & $9.2^{\star}$ & & $90.4^{*}$ & $326.9 *$ \\
\hline Wet machair & 220.9 & 29.2 & $8.4^{*}$ & $9.2^{\star}$ & & $71.5^{*}$ & $61.5 *$ \\
\hline Phragmites beds & 163.8 & & $15.3^{\star}$ & & & & $99.0^{\star}$ \\
\hline Coarse wet pasture & 135.5 & $36.5^{*}$ & $12.4^{\star}$ & $8.5^{\star}$ & 1.3 & 5.6 & $47.9^{*}$ \\
\hline Short wet heath & 107.2 & $29.0^{\star}$ & & & $14.5^{\star}$ & $49.2^{\star}$ & 14.5 \\
\hline Wet acidic grassland & 93.8 & 3.3 & 2.4 & 0.9 & & $11.9 *$ & 50.8 * \\
\hline Dry machair & 66.8 & $37.7^{*}$ & 3.7 & $8.0^{*}$ & 1.7 & $10.7^{\star}$ & 3.7 \\
\hline Plough & 57.4 & $30.6^{\star}$ & & & $26.8^{*}$ & & \\
\hline Uniform wet pasture & 45.0 & 10.2 & 1.2 & $3.8^{\star}$ & & & \\
\hline Coarse dry pasture & 40.3 & $17.6^{\star}$ & $4.4^{\star}$ & $8.8^{\star}$ & $4.4^{\star}$ & & 2.6 \\
\hline Juncus beds & 40.0 & 6.1 & 3.1 & $6.1^{\star}$ & & & 15.4 \\
\hline Dry acidic grassland & 37.0 & 8.1 & 2.0 & $5.4^{\star}$ & & 2.7 & 11.5 \\
\hline Iris beds & 29.0 & 10.6 & $10.6 *$ & 2.6 & & 2.4 & 2.7 \\
\hline Uniform dry pasture & 22.9 & $16.3^{\star}$ & 1.8 & $3.7^{\star}$ & 0.4 & 0.7 & 22.3 * \\
\hline Short dry heath & 18.7 & 7.8 & 3.1 & $7.8 *$ & & & \\
\hline Intensified pasture & 17.5 & 7.0 & 3.5 & $7.0^{\star}$ & & & \\
\hline Blanket bog & 15.0 & 0.4 & 0.4 & & & & 7.1 \\
\hline Dunes & 6.8 & 4.9 & 1.2 & 0.6 & & & \\
\hline Deep heath & 6.8 & 0.6 & 0.1 & & & 0.5 & 3.7 \\
\hline Overall mean density & & 11.8 & 4.I & 3.2 & 2.2 & 8.5 & 17.1 \\
\hline
\end{tabular}

'Located on dry machair.

bred in drier habitats but most of these were associated with small pools nearby. Some adults led newly hatched chicks to distant feeding areas $>1 \mathrm{~km}$ from nests. A number of marked concentrations of pairs with young occurred in wetland areas, particularly those with iris beds providing cover. These were often coastal.

A very high density (100 pairs $\left./ \mathrm{km}^{2}\right)$ of breeding Oystercatchers Haematopus ostralegus was found on abandoned wartime runways at Tiree Airport, the broken concrete there providing excellent camouflage for nests and eggs. However, much use was made of adjacent dry machair and perhaps the old runways should be regarded as only a habitat component in this location. The species showed no particular preference for other habitats.

As with Oystercatchers, a very high density of Ringed Plovers Charadrius dubius was found on the old runways. Ringed Plovers characteristically nested on stony ground and the terrain provided excellent camouflage for nests and eggs. Much use was also made of adjacent dry machair areas. A high density (27 pairs $/ \mathrm{km}^{2}$ ) was also found on ploughed land which was clearly the species' second-preferred choice of habitat. Lower densities ( $<15$ pairs $/ \mathrm{km}^{2}$ ) were found in several other habitats although actual nest locations were probably associated with small areas of stony or sandy terrain within these.
Dunlin Calidris alpina characteristically prefer to breed in moist, boggy or marshy ground, especially when interspersed with pools. The highest densities ( $>70$ pairs $/ \mathrm{km}^{2}$ ) occurred on marsh/fen and wet machair with moderate densities (49 pairs $/ \mathrm{km}^{2}$ ) on short wet heath. Some birds were found breeding in several other habitats but generally associated with small pools or wetter areas.

By far the greatest density of breeding Snipe Gallinago gallinago was found on marsh/fen (327 pairs $/ \mathrm{km}^{2}$ ) although high densities were also found in marshy Phragmites beds (99 pairs/ $\mathrm{km}^{2}$ ) (where the Phragmites was sparse and short). Moderate densities (48-62 pairs $/ \mathrm{km}^{2}$ ) were found on wet machair, wet acidic grassland and coarse wet pasture.

Four pairs of Curlew Numenius arquata were found breeding in deep heath and blanket bog habitats on Coll. This species is a recent colonist. It is also increasing in numbers throughout the Westem Isles (Buxton 1987), following first records of territorial birds in the Uists in 1984 (Pienkowski unpubl.).

When all wader species were considered together, the old disused runways on Tiree appear to be by far the most preferred breeding 'habitat' holding a density of 2500 pairs $/ \mathrm{km}^{2}$. However, only a very small area of this habitat exists, holding just breeding Oystercatchers and Ringed Plovers. Furthermore, the birds on these narrow 
strips undoubtedly make great use of the adjacent habitats (largely dry machair) for feeding and other activities. Clearly old runways alone would be unable to support all the needs of these species during the breeding season!

The remaining results show clearly that two habitat groups are strongly preferred and responsible for the very high numbers of birds breeding: wetlands and machair. Within these groups, marsh/fen, wet machair, reedbeds, coarse wet pasture, short wet heath, wet acidic grassland and dry machair all hold densities of breeding waders in excess of 66 pairs $/ \mathrm{km}^{2}$.

The very wet marsh and fen areas, are clearly extremely important, holding at least 750 pairs of breeding waders per $\mathrm{km}^{2}$. This habitat is especially important for Snipe, Dunlin, Redshank and Lapwing, and grades into both wet machair and Phragmites beds, both of which are important in their own right. Wet machair is especially important for Snipe, Dunlin, Redshank and Lapwing whilst marshy Phragmites beds hold large numbers of Snipe and Redshank. Coarse wet pasture is especially favoured by Lapwing, Redshank and Snipe, whilst short wet heath holds high densities of Lapwing and moderate densities of Dunlin. Wet acidic grassland holds a high density of Snipe. Dry machair holds all six breeding species, but its high overall density is largely due to very high densities of Lapwing.

Habitats generally least preferred on Tiree and Coll are deep heath and dunes, with low densities also found on modified blanket bog, agriculturally intensified pastures and short dry heaths (Table 2).

For five broad habitats which are sub-divided into wet and dry variants (machair, coarse pasture, short heath, acidic grassland and uniform pasture), the densities of breeding waders in all cases are significantly greater in the wet type than in the dry type. The average breeding density in the five wet habitat variants above (120.5 pairs $/ \mathrm{km}^{2}$ ) is over three times greater than on the equivalent dry habitats (average = 37.1 pairs $/ \mathrm{km} 2$ ).

\section{Total wader populations}

Estimates of extrapolated total wader populations for each island are given in Table 3 and indicate that a total of 6020 pairs of breeding waders occur on Tiree and 1330 on Coll. The derivation of these totals is discussed by Shepherd et al. 1988. Table 3 also gives estimates of national populations (JNCC unpublished; Stroud et al. 1990) and the proportion of British populations breeding on each island.

It is clear that both islands, and especially Tiree, are of very major importance for a rich assemblage of breeding waders. The populations of Lapwing, Redshank, Oystercatcher, Ringed Plover, Dunlin and Snipe all of national importance ( $>1 \%$ of national total).

\section{Discussion}

Habitat associations of all species were very similar to those found in the Uists where wetland and machair habitats also hold greatest numbers of birds (Fuller et al. 1986). However, in the Uists, much of the machair is subject to an arable-fallow cultivation cycle (Jackson 1988); about $25 \%$ of the dry machair plain and up to $10 \%$ of the wetter machair areas. Initial single surveys there found that densities of most breeding waders were greater on the arable areas than on fallow. However, longer-term monitoring (Fuller \& Percival 1988) has shown that in any one location, breeding numbers are not associated with any particular stage of the cultivation/ fallow cycle (i.e. habitat related), but rather constant in particular local areas. These areas

Table 3. Present estimates of British breeding wader populations (from Stroud et al. 1990), estimated total breeding wader populations on Tiree and Coll and percentages of national populations (in parentheses) breeding on Tiree and Coll. All totals in pairs.

\begin{tabular}{lcrr}
\hline Species & $\begin{array}{c}\text { British } \\
\text { population }\end{array}$ & Tiree & Coll \\
\hline Lapwing & 215000 & $3000(1.4 \%)$ & $500(0.2 \%)$ \\
Redshank & 32500 & $600(1.8 \%)$ & $125(0.4 \%)$ \\
Oystercatcher & 38000 & $620(1.6 \%)$ & $150(0.4 \%)$ \\
Ringed Plover & 8400 & $250(3.0 \%)$ & $30(0.3 \%)$ \\
Dunlin & 9150 & $350(3.8 \%)$ & $20(0.2 \%)$ \\
Snipe & 30000 & $1200(4.0 \%)$ & $500(1.7 \%)$ \\
Curlew & 35500 & 0 & 4 \\
Total & & 6020 & 1330 \\
\hline
\end{tabular}


clearly have differing underlying characteristics which seem to affect wader distributions. Alternatively this may be an effect of natal philopatry such that birds return to areas where they are reared and/or first breed.

Old runways aside, the greatest concentration of breeding waders were found on marshes and fens, wet machair, Phragmites beds, coarse wet pasture, short wet heath and wet acidic grassland. It is the traditional island crofting agriculture that has maintained the mosaic of these important areas. Should extensive drainage and intensification occur, these habitats would change into dry pastures, dry heath and intensified pasture - habitats holding much lower densities of breeding birds.

The low-intensity crofting agriculture is based around an extensive pastoralism. Large numbers of cattle are reared, especially on Tiree, and these are grazed on the machair throughout the winter (Harrison 1989). Their grazing and dunging maintains these permanent grasslands in a suitable state for breeding waders. The role of cattle in creating and maintaining micro-topographical features important in nest site selection, and nest and chick camouflage has been highlighted by Jackson (1988). Pastoralism also results in some small-scale arable cultivation for hay and other cattle fodder, as well as limited cereal growing. Although these ploughed areas are largely avoided by waders on Coll and Tiree, they provide suitable conditions for traditional birds of weedy arable fields such as Corn Bunting Emberiza calandra and the internationally rare and endangered Corncrake Crex crex (Cadbury 1989).

Agricultural intensification also becomes particularly damaging to bird populations where it encourages large-scale uniformity of habitat. Many breeding waders use a variety of habitats during the course of the breeding season, a particularly good example being the Redshank. The species prefers a mosaic of habitats; rank vegetation to provide nesting cover, with suitable wetland feeding sites nearby as observed in the Outer Hebrides (Chandler \& Walker 1985, Jackson 1988). Land-use changes which encourage large-scale agricultural uniformity will be less attractive to waders than the maintenance of existing small-scale habitat mosaics. Since there is no information on breeding productivity in different habitats on the islands, and since areas of highest breeding density do not always equate to areas of highest productivity (Stroud et al. 1990), this is another reason to approach conservation of these wader habitats at an island-wide scale.
Virtually the whole European extent of machair has been surveyed for breeding waders since 1983. A survey of breeding waders on machair in northwest Ireland between north Donegal and Galway Bay (Nairn \& Sheppard 1985) revealed nine species of breeding waders, although densities were much lower than those on Tiree, Coll or the Uists. Furthermore, Oystercatchers were almost absent and there were small numbers of Redshank and Ringed Plover. The machair there differs in being both smaller in total area and much more fragmented than in the Uists. A survey of breeding waders on marsh and marginal grassland areas of Orkney (Campbell et al. 1988) revealed low densities compared to Tiree and the Uists and it is clear that comparable machair type habitats are extremely restricted within both the Orkney and Shetland island groups (Berry \& Johnston 1980). On Islay, only a limited area of machair occurs and although important as one component of an important mosaic of traditionally managed biotopes (Bignal et al. 1989), in absolute terms it only holds small numbers of waders.

Fuller et al. (1986) concluded that breeding wader communities of the Uist machairs were unique in Europe for their species composition and very high densities of breeding birds. Comparable and generally slightly higher overall densities were found on Tiree and Coll. These Hebridean machairs hold large populations, have valuable species assemblages and are important in maintaining the range of several breeding waders (and other waterfowl: Stroud 1989) within the British Isles. They are thus of international conservation importance (Stroud et al.1990).

Comparisons of the detailed relationship between certain agricultural activities and wader densities in different machair areas are confounded by geographical differences in density indicated above. The type of crofting on the Uists differs from that on Coll and Tiree in several respects, and without further work specifically relating agriculture to waders it is not possible to clearly distinguish effects. It is clear, however, from comparisons between habitat types on Coll and Tiree, that more intensive forms of uniform agriculture are less attractive to breeding waders than the mosaics of habitats (often wetlands) resulting from low-intensity crofting.

Machair aside, there are very few other locations in Britain holding comparable densities of breeding waders. Saltmarshes of the Ribble Estuary and the Wash hold over 70 pairs $/ \mathbf{k m}^{2}$ (mainly Redshanks: Hale \& Ashcroft 1982) and 
some North Kent grazing marshes hold over 50 pairs $/ \mathrm{km}^{2}$ (Williams et al. 1983), but in all these cases birds breed in fairly small areas. The Ouse and Nene Washes, the Derwent Ings and the Somerset Levels are also major lowland wader breeding sites, but on Tiree and Coll densities are even higher and species assemblages are different (cf. Fuller et al. 1986).

Elsewhere in Europe, densities of breeding waders commonly found on wetlands on Tiree and Coll would be considered quite exceptional, recorded from only a few areas of Iceland (references in Kirby \& Gudmundsson 1987), very rich natural fen systems in Poland (Dyrcz \& Witowski 1987) and some areas of the
Low Countries (Beintema 1983).

Nowhere in Europe outwith the Southern Isles, Tiree, and Coll, do Oystercatchers, Ringed Plovers, Lapwings, Dunlin, Snipe and Redshank breed in such numbers and in such close proximity. Their continued conservation is of great importance. It is important to ensure that the traditional forms of crofting agriculture, which have maintained this intimate mosaic of wetland bird habitats, are sustained, for without it, the suitability of most areas for breeding waders will decline. An Environmentally Sensitive Area-type scheme for the Inner Hebrides would benefit conservation by encouraging existing sympathetic crofting practises.

The survey was funded by the Chief Scientist Directorate of NCC as part of its Moorland Bird Study (Project No. Bi202). We are greatly indebted to the many crofters, farmers and landowners for allowing unrestricted access to their land. Without their assistance and consent, this survey would not have been possible.

Field survey was principally undertaken by Mick Green and Andy Knight, with assistance from Keith Bailey, Roger Broad, Mike Everett, James Cadbury, Peter Clement, Jerry Moore, Carl Mitchell, Martin Nugent, John Palfrey and Mike Pienkowski. Mick Green and Andy Knight also assisted with analysis.

Peter Wormell (NCC), Roger Broad (RSPB) and Donald Harrison (West of Scotland College of Agriculture) kindly gave much help and advice during the preparation of the survey. We are particularly grateful to Dr Mike Pienkowski for his support and encouragement during the survey and also to Dr Eric Bignal, Mick Green and Andy Knight for helpful comments on an early draft.

\section{References}

Bientema A.J. 1983. Wet meadows in temperate Europe, threatened by agriculture. In: Evans, Hafner \& L'Hermite (Eds.) Shorebirds and Large Waterbirds Conservation, EEC symposium 1983:26-33.

Berry, R.J. \& Johnston, J.L. 1980. The natural history of Shetland. Collins, London.

Bignal, E.M., Curtis, D.J. \& Matthews, J.L. 1989. Islay: Land-types, bird habitats and nature conservation. Part 1: Land-use and birds on Islay. NCC, Chief Scientist Directorate. Report No. 809 , Part 1.

Buxton, N.E. 1987. The numbers and distribution of Curlews in the Western Isles. Hebr. Nat. 9:51-55.

Caird, J.B. 1979. Land-use in the Uists since 1800. Proc. Roy. Soc. Edinb. 77B:505-526.

Campbell, L.H., Christer, W.G., Stenning, J.M., Davey, P.R. \& Meek, E.R. 1989. Wetland and marginal moorland in Orkney. NCC, Chief Scientist Directorate commissioned research Report No. 891.

Chandler, A.J. \& Walker, D.F. 1985. Family group movements by breeding Redshanks on South Uist. Wader Study Grp. Bull. 45:29-31.

Dyrcz, A. \& Witowski, J. 1987. Numbers, distribution and interspecific relations of breeding waders in natural Biebrza fen and adjacent reclaimed marsh. Wader Study Grp. Bull. 51:42-44.

Fuller, R.J. 1982. Bird Habitats in Britain. T. \& A.D. Poyser, Calton.

Fuller, R.J. \& Percival, S.M. 1988. Surveys of breeding waders in the southern isles of the Outer Hebrides, 1983-1987. NCC, Chief Scientist Directorate commissioned research Report No. 904.

Fuller, R.J., Reed, T.M., Buxton, N.E., Webb, A., Williams, T.D. \& Pienkowski, M.W. 1986. Populations of breeding waders Charadrii and their habitats on the crofting lands of the Outer Hebrides, Scotland. Biol. Conserv. 37:333-361.

Green, R.E. 1985. Estimating the abundance of breeding Snipe. Bird Study 32:141-149. 
Hale, W.G. \& Ashcroft, R.P. 1982. Pair formation and pair maintenance in the Redshank Tringa totanus. Ibis 124:471-490.

Harrison, D.M. 1989. Agriculture and machairs on Tiree and Coll: a summary. In: D.A. Stroud (Ed.) The Birds of Coll and Tiree: status, habitats and conservation. Pp. 19-24. Nature Conservancy Council/Scottish Ornithologists' Club. Edinb.

Jackson, D.B. 1988. Habitat selection and breeding ecology of three species of waders in the Western Isles of Scotland. Ph.D. Thesis, Durham University.

Kirby, J. \& Gudmundsson, G. 1987. Densities of breeding waders in Heidmork City Park, south-west Iceland. Wader Study Grp. Bull. 50:20-24.

Naim, R.G.W. \& Sheppard, J.R. 1985. Breeding waders of sand dune machair in north-west Ireland. Ir. Birds 3:53-70.

Reed, T.M. 1986. Diurnal and seasonal variability in the breeding behaviour and detectability of Snipe. Wader Study Grp. Bull. 46:25-28.

Reed, T.M. \& Fuller, R.J. 1983. Methods used to assess populations of breeding waders on the machair of the Outer Hebrides. Wader Study Grp. Bull. 39:14-16.

Reed, T.M., Currie, A. \& Love, J.A. 1983. The birds of the Inner Hebrides. Proc. Roy. Soc. Edinb. 83B:449-472.

Ritchie, W. 1976. The meaning and definition of machair. Trans. Proc. Bot. Soc. Edinb. 42:431-440.

SDD. 1988. An Agricultural Development Programme for Scottish Islands. Scottish Development Department Report.

Shepherd, K.B. 1988. Ornithological observations made during visits to the Isle of Tiree, Argyll in February 1987 and spring 1988. NCC, Chief Scientist Directorate commissioned research Report No. 856.

Shepherd, K.B., Green, M., Knight, A.C. \& Stroud, D.A. 1988. The breeding birds of Tiree and Coll in 1987/88 with special emphasis on breeding waders. NCC, Chief Scientist Directorate commissioned research Report No. 827.

Stroud, D.A. (Ed.). 1989. Birds on Coll and Tiree: status, habitats and conservation. Scottish Ornithologists' Club/Nature Conservancy Council, Edinburgh.

Stroud, D.A., Reed, T.M., Pienkowski, M.W. \& Lindsay, R.A. 1987. Birds, Bogs and Forestry: the peatlands of Caithness and Sutherland. NCC, Peterborough.

Stroud, D.A., Mudge, G.P. \& Pienkowski, M.W. 1990. Protecting internationally important bird sites: a review of the EEC Special Protection Area network in Great Britain. NCC, Peterborough.

Vose, P.B., Powell, H.G. \& Spence, J.B. 1956. The machair grazings of Tiree, Inner Hebrides. Trans. Proc. Bot. Soc. Edinb. 37:84-110.

Williams, G., Henderson, H., Goldsmith, L. \& Spreadborough, A. 1983. The effects on birds of land drainage improvements in the North Kent marshes. Wildfowl 34:33-47.

Wormell, P. 1989. Bird habitats on Coll and Tiree. In: Stroud, D.A. (Ed.) Birds on Coll and Tiree: status, habitats and conservation. Pp. 9-18. Scottish Ornithologists' Club/Nature Conservancy Council, Edinburgh.

K.B. Shepherd and David A. Stroud ${ }^{1}$, Ornithology Branch, Chief Scientist Directorate, Nature Conservancy Council, Northminster House, Peterborough, PEI IUA.

${ }^{1}$ Currently: Ornithology and Landscape Ecology Branch, Joint Nature Conservation Committee, Monkstone House, City Road, Peterborough, PE1 IJY. 